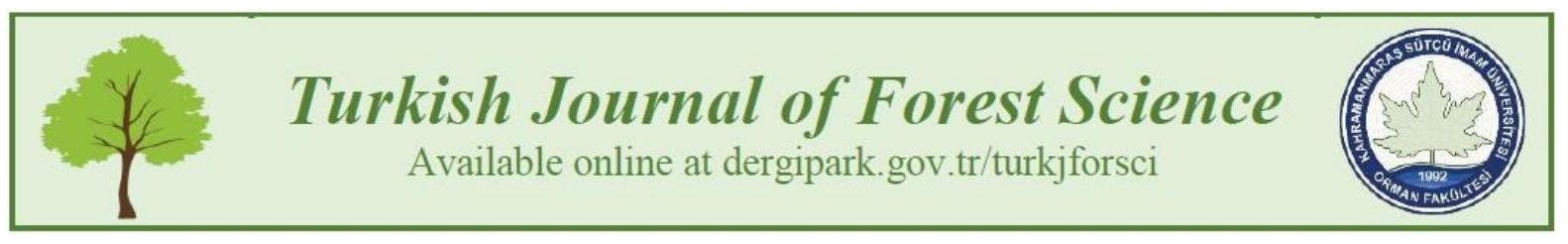

\title{
WEB-BASED TREE INFORMATION SYSTEM: A CASE STUDY OF KAHRAMANMARAS, TURKEY
}

\author{
Hakan OGUZ ${ }^{1, *}$, Alper UZUN², Şule KISAKÜREK ${ }^{1}$ \\ ${ }^{1}$ Department of Landscape Architecture, Faculty of Forestry, Kahramanmaras Sutcu Imam University, \\ Kahramanmaras, Turkey \\ ${ }^{2}$ Department of Forest Engineering, Faculty of Forestry, Kahramanmaras Sutcu Imam University, \\ Kahramanmaras, Turkey \\ *Corresponding author: hakan@ksu.edu.tr
}

Hakan OGUZ: https://orcid.org/0000-0002-0855-2032

Alper UZUN: https://orcid.org/0000-0002-2577-7460

Şule KISAKÜREK: https://orcid.org/0000-0002-5005-8476

Please cite this article as: Oguz, H., Uzun, A. \& Kisakürek, Ş. (2020) Web-based tree information system: A case study of Kahramanmaras, Turkey. Turkish Journal of Forest Science, 4(1), 160-171.

\section{ESER BILGISI / ARTICLE INFO}

Araştırma Makalesi / Research Article

Geliş 20 Mart 2020 / Received 20 March 2020

Düzeltmelerin gelişi 6 Nisan 2020 / Received in revised form 6 April 2020

Kabul 17 Nisan 2020 / Accepted 17 April 2020

Yayımlanma 30 Nisan 2020 / Published online 30 April 2020

\begin{abstract}
Trees are not only true assets in urban areas but also part of our community's infrastructure. Therefore, they require care and maintenance same as other public properties. Without proper care, trees may cause personal injury or property damage. The main objective of this study was to develop a web-based tree information system for the two main boulevards of Kahramanmaras, Prof. Dr. Necmettin Erbakan and Alpaslan Turkeş boulevards. This research was conducted in two parts. In the first part of this study, an inventory for small and large trees on the median strip of the boulevards was conducted. GPS coordinates, tree height, diameter at breast height ( $\mathrm{dbh})$, crown diameter, tree type (Deciduous/Evergreen) of each individual tree were gathered by doing ground measurements and field observations. Attributes of 774 trees were retrieved during the inventory. After tree inventory, a total of 11 tree species were identified where Pinus pinea was found to have the largest number of trees with 321 in the study area. In the second part of this research, a database was created for all the trees inventoried and then two web applications were created. The first one was web application with interactive legend for web-based tree information system that was created for general public using ArcGIS Online. Attributes of each tree are given to the user via pop-up window in this web application. This web application is publicly accessible. Users may interact with the web application via browsers by personal computers, tablets, or smartphones. The second web application was created for a site manager who has authority to add trees in the web-based tree information system.
\end{abstract}

Keywords: ArcGIS Online, GIS, Inventory, Urban Trees, Web Map, Web App. 


\section{WEB-TABANLI Ă̆AÇ BILGİ SİSTEMI: KAHRAMANMARAŞ, TÜRKIYYE ÖRNEĞİ}

ÖZET: Ağaçlar sadece kentsel alanlardaki gerçek varlıklar değil, aynı zamanda topluluğumuzun altyapısının bir parçasıdır. Bu nedenle, diğer kamu mülkleriyle aynı bakım ve bakıma ihtiyaç duyarlar. Uygun bakım olmadan, ağaçlar kişisel yaralanmaya veya mülkiyet hasarına neden olabilir. Bu çalışmanın temel amacı, Kahramanmaraş'ın iki ana bulvarlari olan Prof. Dr. Necmettin Erbakan ve Alparslan Türkeş için web-tabanlı bir ağaç bilgi sistemi geliştirmektir. Bu araştırma iki bölüm halinde tamamlanmıştır. Bu çalışmanın ilk bölümünde her iki bulvarın refujlerindeki ağaçlar için bir envanter calışması yapılmıştır. Her bir ağacın koordinatları, boyu, göğüs yüksekliğindeki çapı (dbh), tepe tacı genişliği, ve ağaç türü (iğneli/yapraklı) yer ölçümleri ve saha calışması yapılarak elde edilmiştir. Envanter calışmasında toplam 774 ağacın bilgileri elde edilmiştir. Envanter çalışması sonucunda 11 farklı tür tespit edilmiş ve Fıstık çamı 321 ağaç ile en fazla sayiya sahip tür olarak bulunmuştur. Araştırmanın ikinci bölümünde, envanteri yapılan ağaçların özellikleri bir veritabanına aktarıldıktan sonra ArcGIS Online ile iki adet web uygulaması (Web App) oluşturulmuştur. İlk uygulamada, her bir ağacın özellikleri kullanıcılara pop-up pencere sayesinde sunulmaktadır. Interaktif lejanta sahip olan bu web uygulaması internet bağlantısı olan herkesin erişimine açıktır. Bu web uygulamasına kişisel bilgisayar, tablet, veya akıllı telefonlar ile erişilebilmektedir. İkinci uygulama ise web-tabanlı ağaç bilgi sistemine veri ekleme yetkisi olan web yöneticisi için oluşturulmuştur.

Anahtar kelimeler: ArcGIS Online, CBS, Envanter, Kent Ağaçları, Web Haritası, Web Uygulamasi.

\section{INTRODUCTION}

Trees have several benefits for human being such as improving water, soil, and air quality, lowering energy bills with their shade, providing shelter for wildlife, and adding beauty, aesthetics and value to our house or land, and increasing recreational opportunities (Wolf, 1998; Li \& Qi, 2003; Gül et al., 2005; Sabuncu et al., 2013; Bruno et al., 2014). They are also renewable resources and provide ecologic, social, cultural, economic, and esthetic benefits to communities and local governments. (Gül vd., 2014).

With tree inventory, the total number of trees, species, individual tree properties, geographical location, health and maintenance status of individual tree can be obtained. Thus, all kind of data related to urban trees should be gathered and imported into geographic information system (GIS). By doing tree inventory in the urban parks with the help of GIS, it could be possible to assess the current status of the trees, sustainable and effective planning, design, and management for the future. Unfortunately, there are few studies related to webbased tree inventory and almost all of them were done in this decade (Abd-Elrahman et al., 2010; Gül et al., 2014; Oguz and Kisakurek, 2016a; Oguz and Kisakurek, 2016b; Oguz et al., 2017; Oguz and Isbir, 2017; Oguz et al., 2018; and Oguz and Çayraz, 2019).

The main objective of this study was to develop a web application of a web-based tree information system for trees on median strip of Prof. Dr. Necmettin Erbakan and Alpaslan Turkeş boulevards in Kahramanmaraş Turkey. The first step of this study was conducting an 
inventory for trees in the boulevards. With this study, geographic location and individual attributes such as tree height, dbh, crown diameter, and type of each tree were obtained via ground measurements and field observations. All the data gathered during the inventory were imported into ESRI ArcGIS in order to create a geodatabase. Finally, a web application for web-based tree information system was developed using ArcGIS Online. In addition, a web map and a web application to delete or edit a feature in the web-based tree information system and a web application to add a new tree to the web-based tree information system for a web manager who has authority to add trees to the web-based tree information system were created.

\section{MATERIALS AND METHODS}

In this study, web application of the web-based tree information system for the two main boulevards of Kahramanmaraş, Prof. Dr. Necmettin Erbakan and Alpaslan Türkeş boulevards. This research was completed in two parts. In the first part of this study, an inventory for small and large trees on the median strip of the boulevards was conducted. GPS coordinates, tree height, dbh, crown diameter, tree type of each individual tree were gathered by doing field measurements and observations. Attributes of 774 trees were retrieved during the inventory.

The first part of this study was carrying an inventory for trees on the boulevards. In this particular study, Leica Zeno $20^{\mathrm{TM}}$ was used to record accurate geographic locations of each tree in the study area. Haglof Vertex IV was employed in order to measure the tree heights. A simple tape measure was used to obtain dbh. Canopy diameter of each tree was also measured and recorded. An ID number was given to each tree on the boulevards and then tree was photographed. Scientific and Turkish names of each tree were also recorded. Uses of trees in the landscape and potential benefits and/or hazards of trees were gathered and recorded successfully.

In the second part of this research, a database was created for all the trees inventoried and then two web applications were created. The first one was web application with interactive legend for web-based tree information system that was created for general public using ArcGIS Online. Attributes of each tree are given to the user via pop-up window in this web application. This web application is publicly accessible to anyone who has access to internet. Users may interact with the web application via browsers in personal computers, tablets, or smartphones. The second web application was created for a site manager who has authority to add trees in the web-based tree information system.

The Boulevards of Prof. Dr. Necmettin Erbakan and Alpaslan Türkeş are the two of the longest located in the Province of Kahramanmaraş, Turkey. A total of 774 trees were inventoried on median strip of the boulevards located in the district of Onikişubat, Kahramanmaraş, Turkey. The total length of the boulevards is approximately $7.3 \mathrm{~km}$ as illustrated in Figure 1 below. 


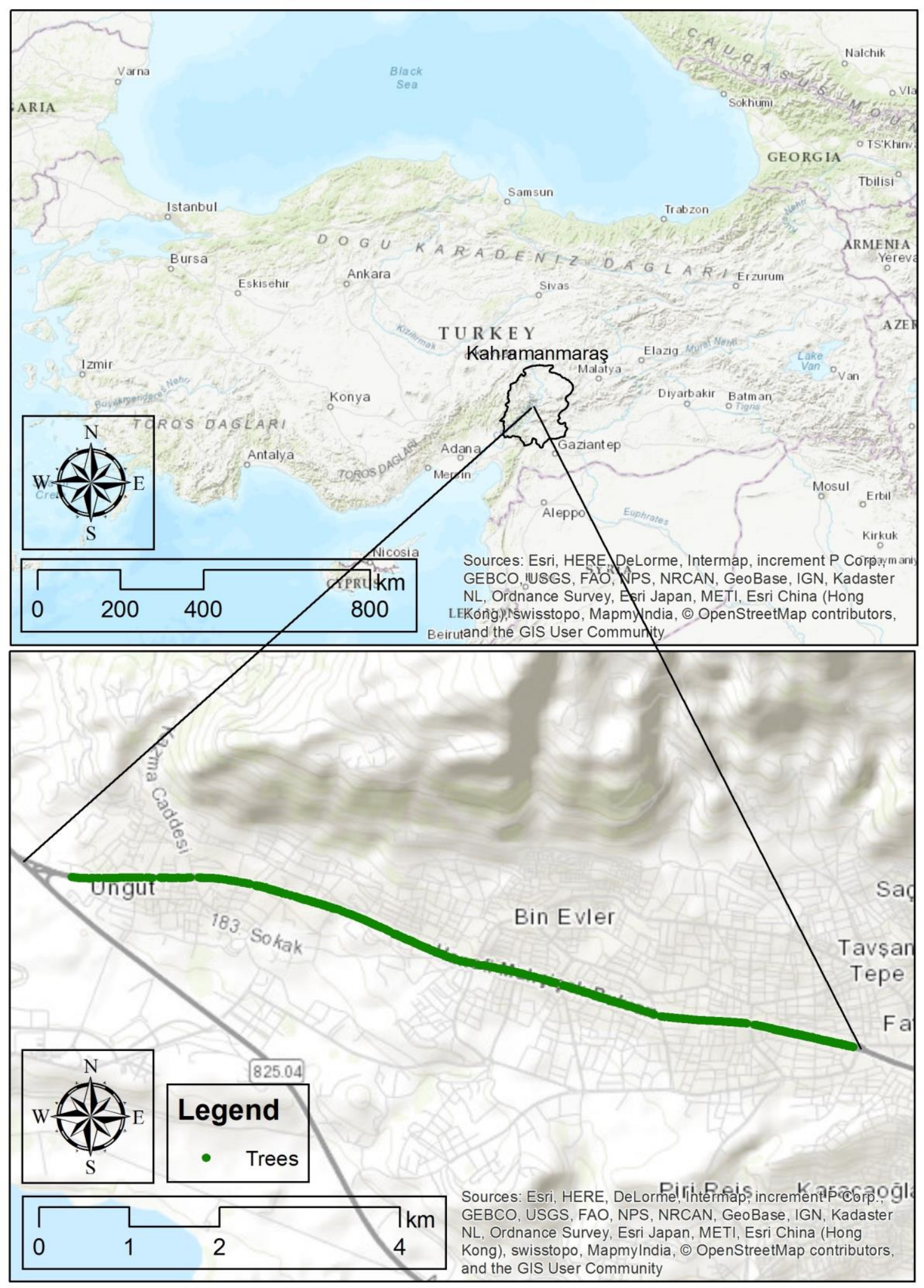

Figure 1. The location map of the study area 


\section{RESULTS}

As a result of this study, 11 tree species (among 774 trees) were identified on the boulevards of Prof. Dr. Necmettin Erbakan and Alpaslan Türkeş. These species are Pinus pinea, Platanus orientalis, Cupressus sempervirens, Robinia pseudoacacia, Fraxinus angustifolia, Cupressus arizonica, Fraxinus excelsior, Cedrus sp, Cedrus Libani, Morus alba, and Pinus brutia. Then, two web applications were developed for web-based tree information system. The first one was web application with interactive legend for web-based tree information system that was created for general public using ArcGIS Online. Attributes of each tree are given to the user via pop-up window in this web application. This web application is publicly accessible to anyone who has access to internet. Users may interact with the web application via browsers in personal computers, tablets, or smartphones. The second web application was created for a site manager who has authority to add trees in the web-based tree information system. The web application for the web-based tree information system with interactive legend was illustrated in Figure 2 below.

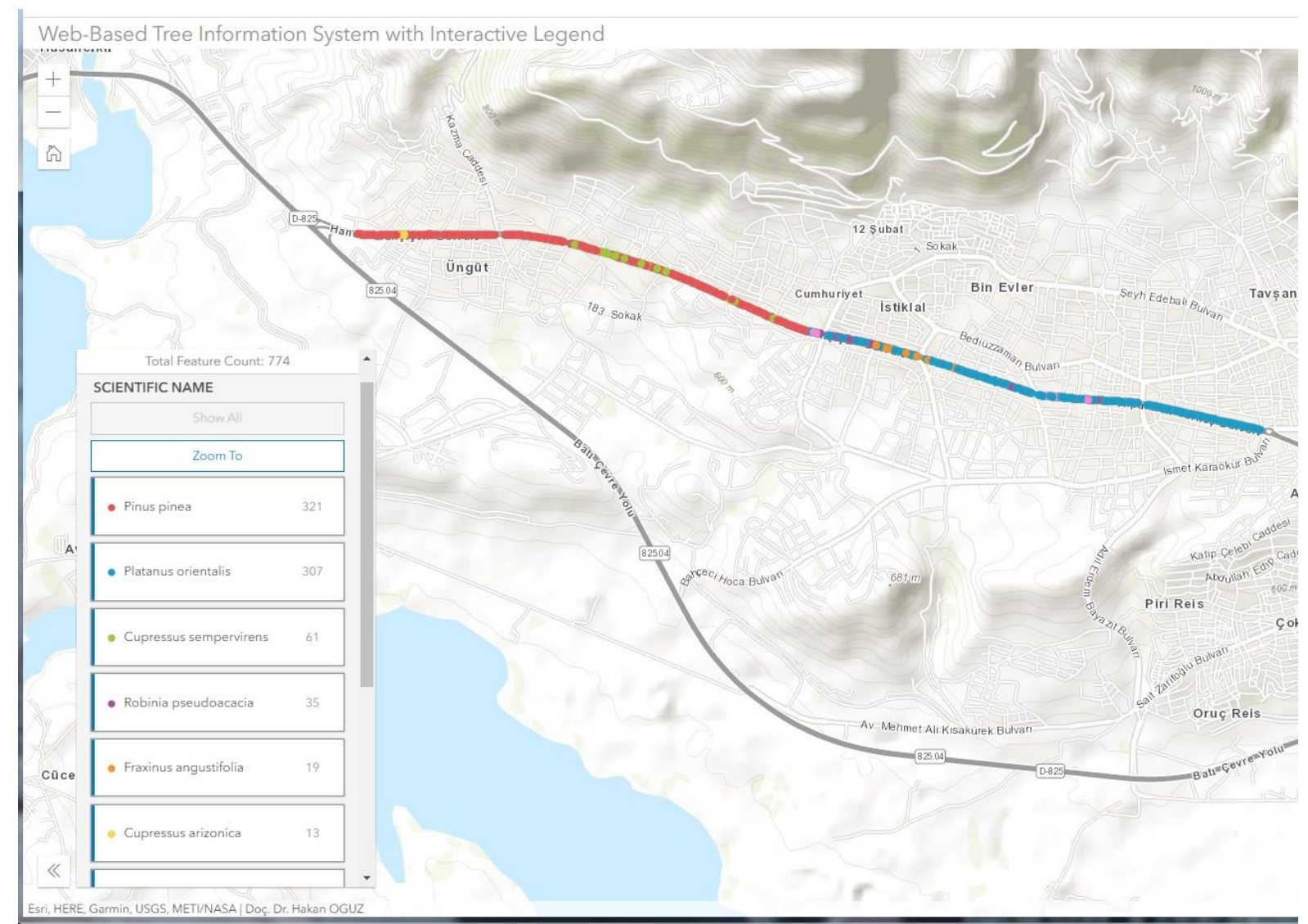

Figure 2. Geographic distribution of 11 tree species in the web-based tree information system with interactive legend

With interactive legend, users are able to see the tree species by clicking the interactive legend as illustrated in Figures 3-13 below. 


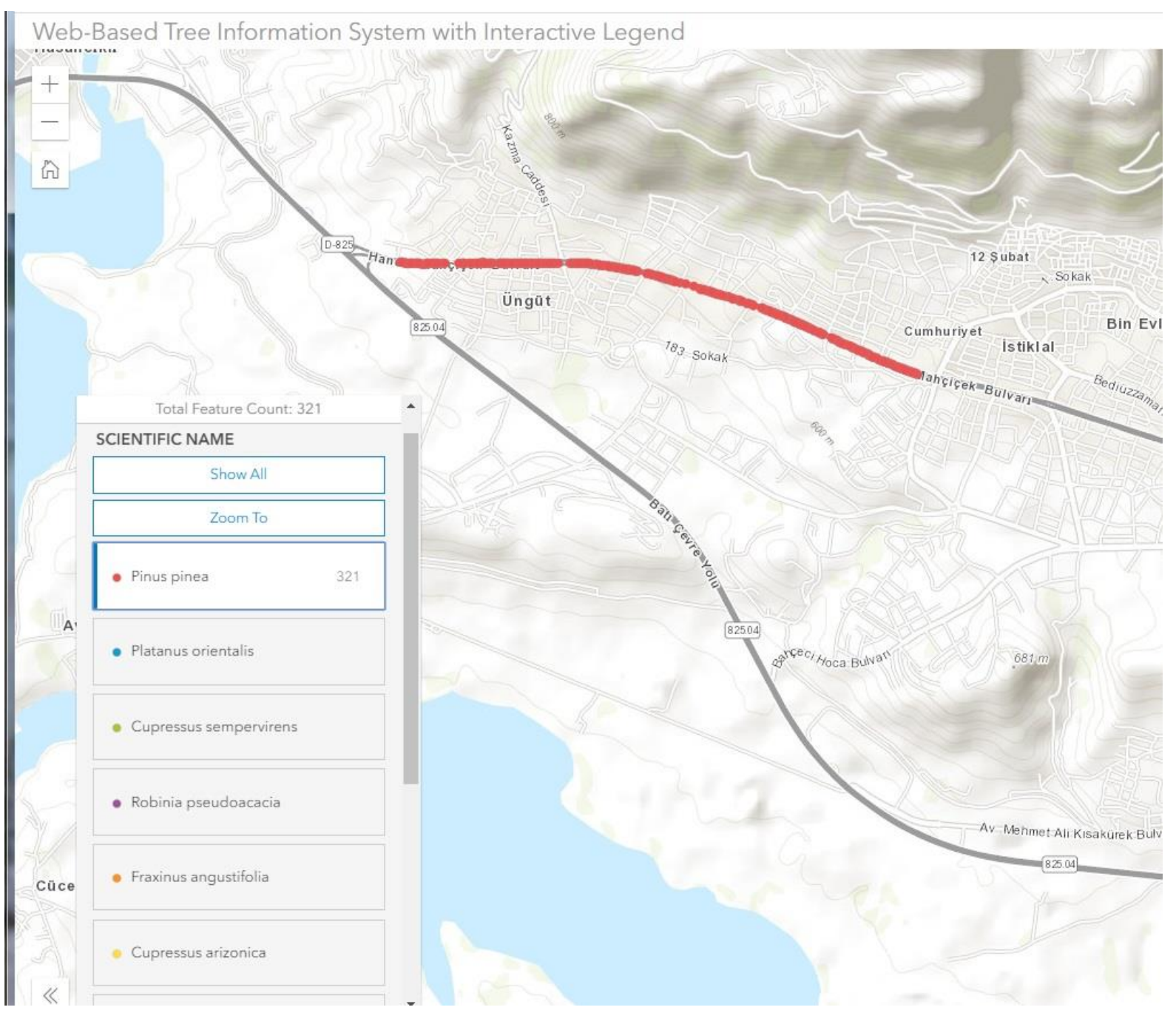

Figure 3. Distribution map of Pinus pinea in the study area.

Pinus pinea has the largest distribution with 321 trees in the study area as shown in Figure 3 above. Platanus orientalis takes the second place with 307 trees as illustrated in Figure 4 below. The total number of trees in the study area and the number of trees in each species are given in the interactive legend. According to tree type, evergreen trees take the lead with 401 while deciduous trees are the second with 373 trees in the study area. 


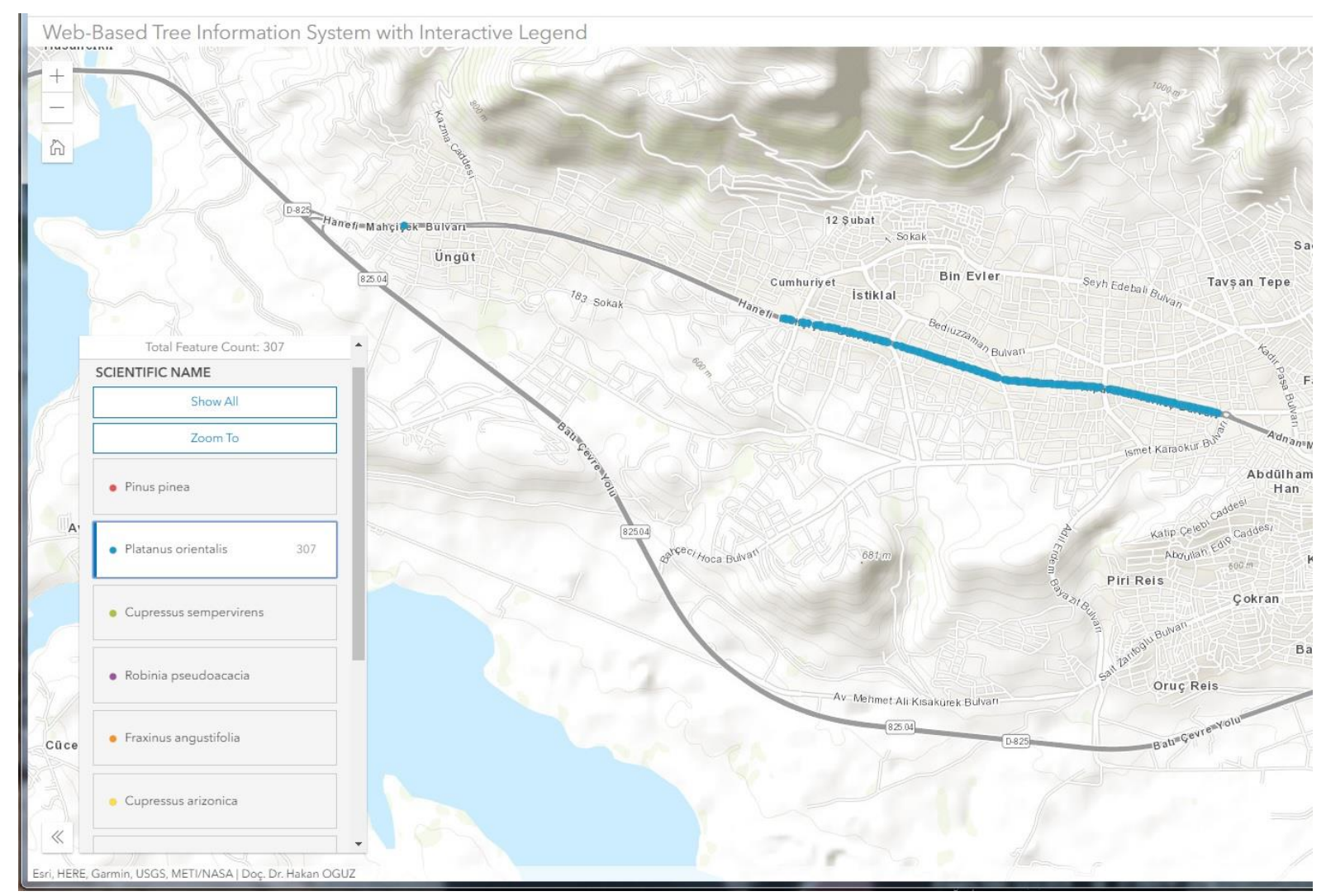

Figure 4. Distribution map of Platanus orientalis in the study area.

A popup window is displayed when a user clicks on a specific tree in the web app as illustrated in Figures 5 and 6. ID number, height, dbh, crown diameter, geographic location, Turkish and Scientific names, application areas, potential hazards/benefits, and a picture of the tree is given to the user via popup window. A full sized image of the tree is also provided when a user clicks on a thumbnail image of the tree or clicks the link on popup window as shown in Figures 6, 7 and 8 below. 
Oguz, H., Uzun, A. \& Kisakurek, S. / Turkish Journal of Forest Science 4(1) 2020: 160-171

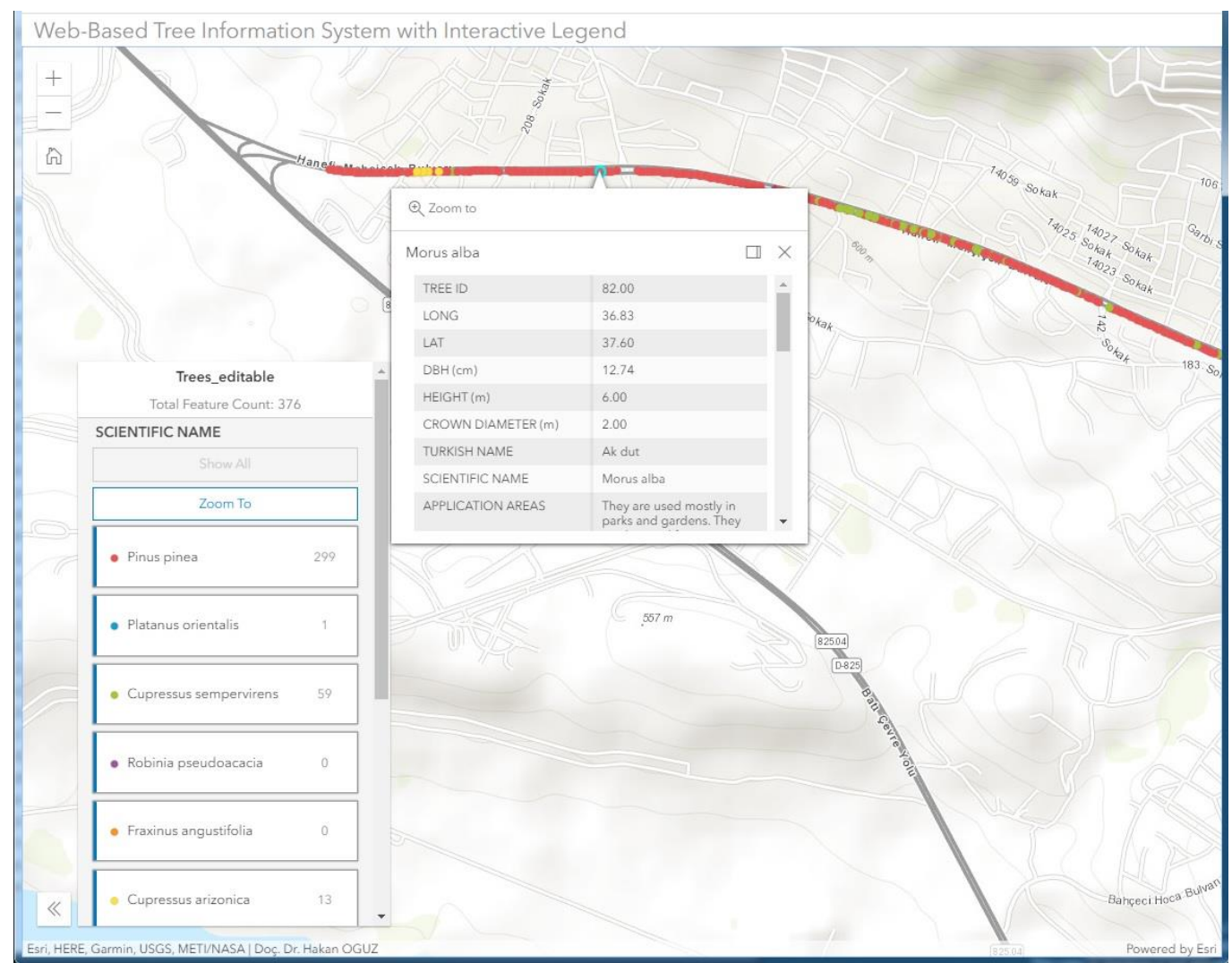

Figure 5. Tree attributes are given through a popup window

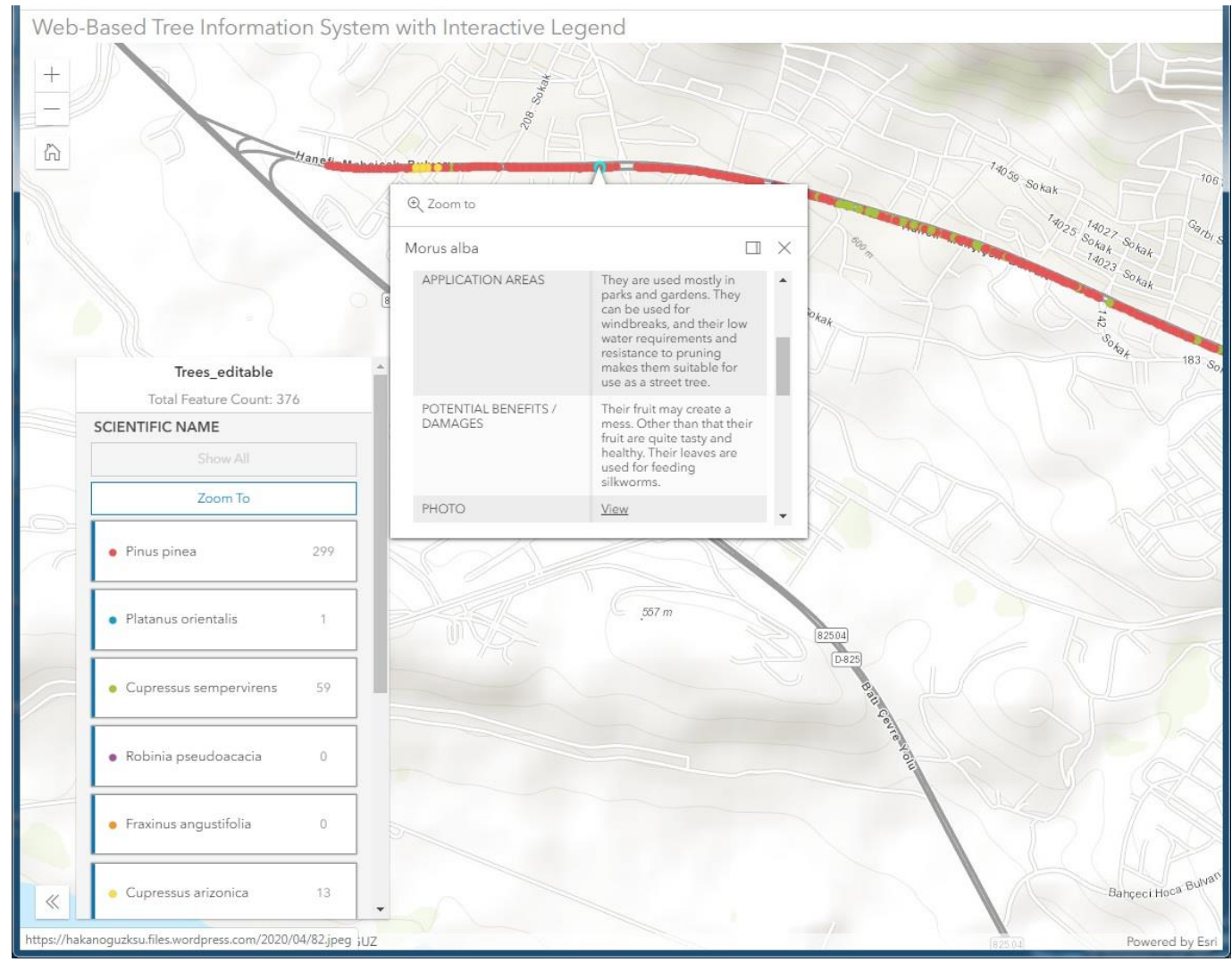

Figure 6. Tree attributes are given through a popup window 
Oguz, H., Uzun, A. \& Kisakurek, S. / Turkish Journal of Forest Science 4(1) 2020: 160-171

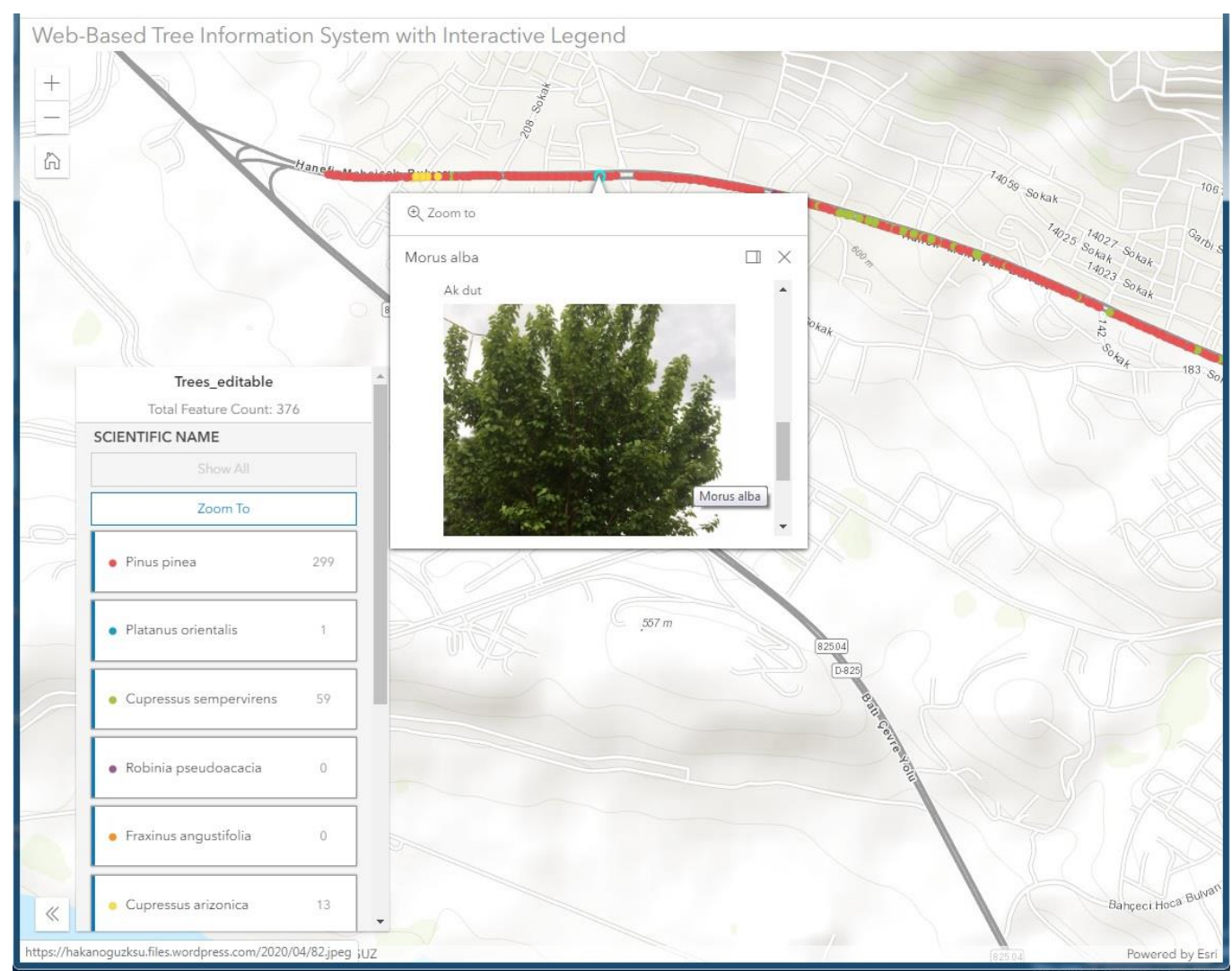

Figure 7. Thumbnail image of a tree on popup window

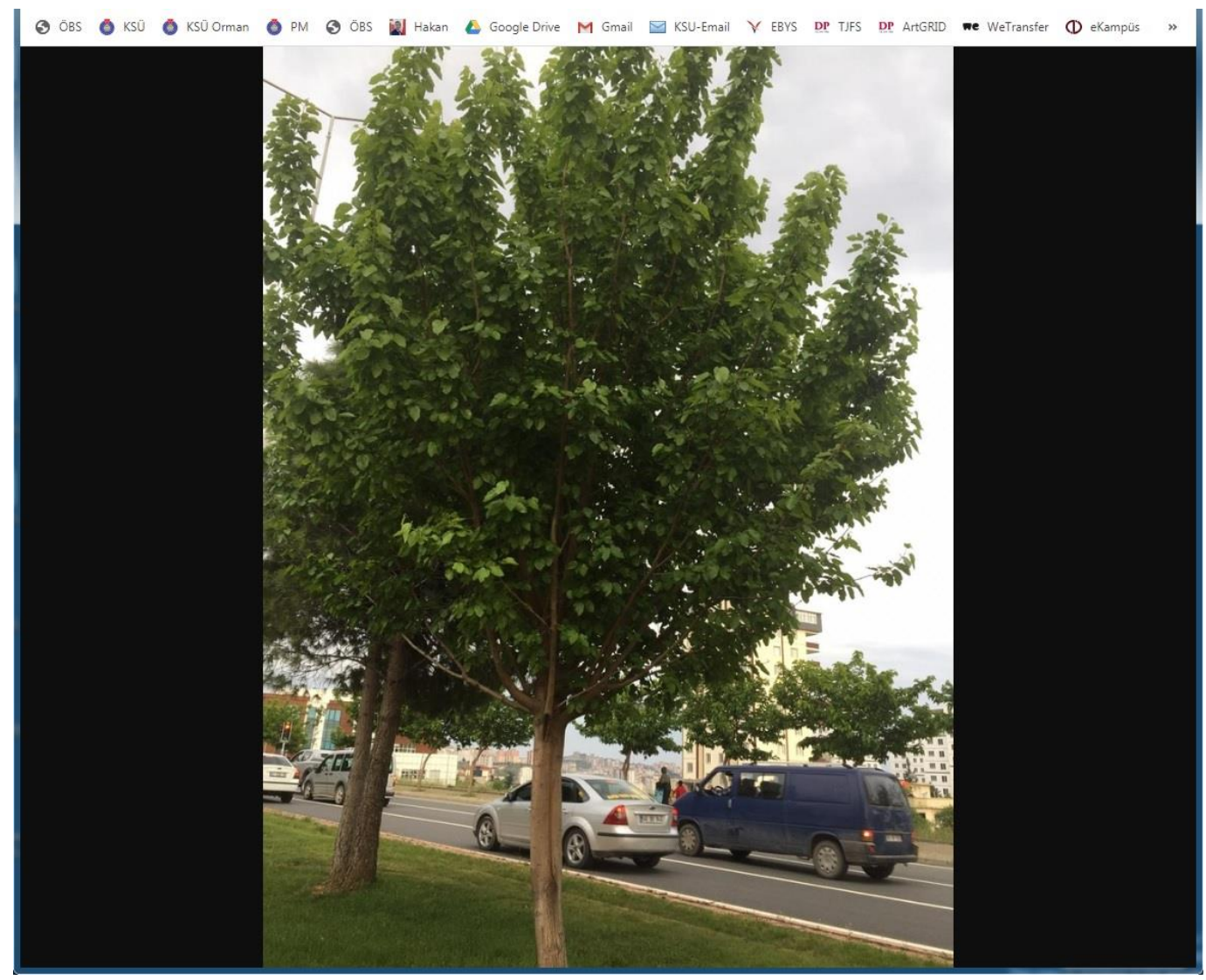

Figure 8. Full sized image of a tree 
Another web application was developed for a person who has authority to manage, add, remove, update and edit the features in the web-based tree information system as illustrated in Figure 9 below. Authorized manager can add or remove a tree and edit attributes of current trees in the information system. This web application is only accessible to web manager and not general public.

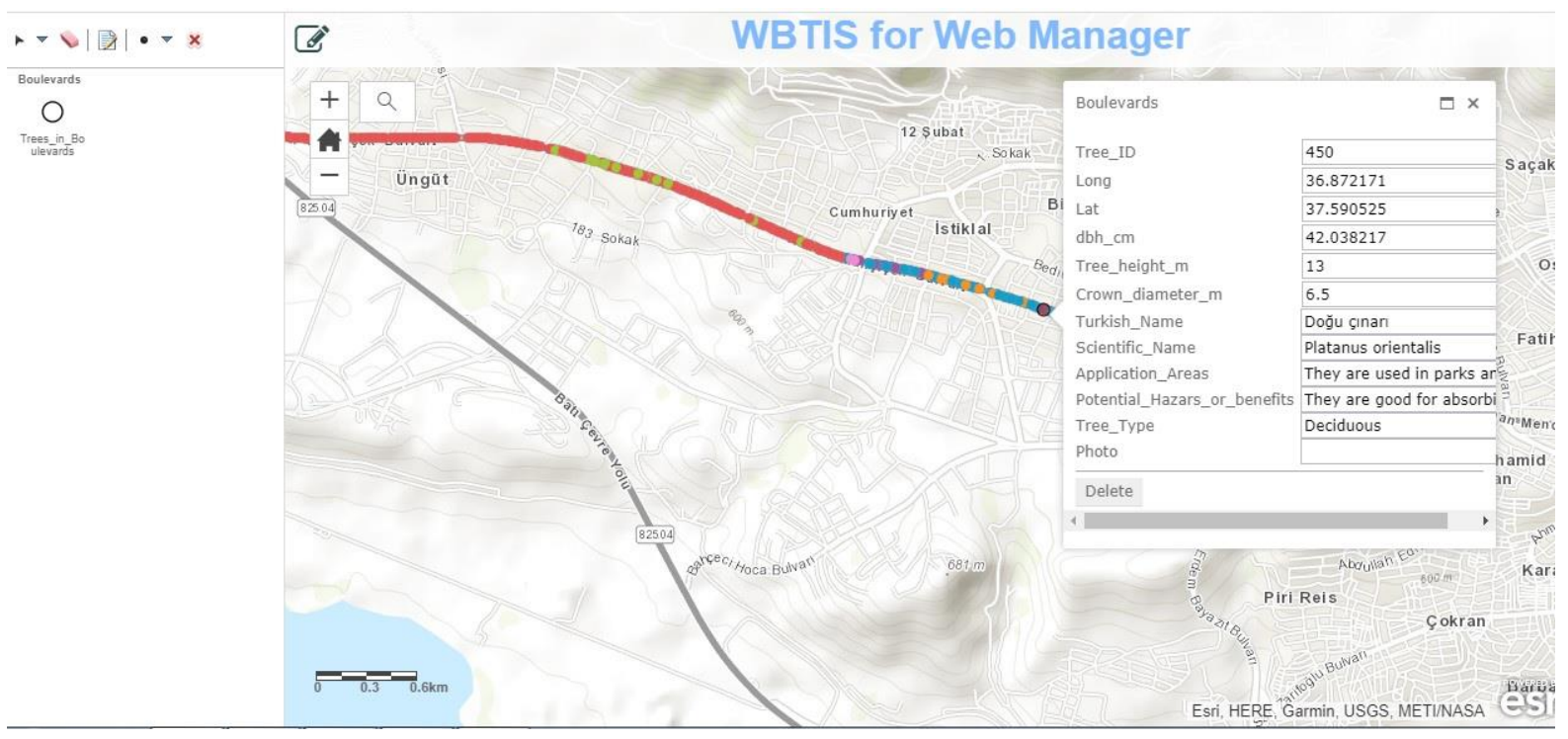

Figure 9. Web Application of Web-Based Tree Information System (WBTIS) for a web manager

\section{CONCLUSIONS}

The subject of this study was conducting an inventory on tree species with the developing technology. This issue is gaining importance today in terms of planning and design studies for the future. Because in our country, there are deficiencies in reaching tree inventories on the web. Therefore, the implementation of this work in Turkey is still important.

The web application developed in this study is publicly accessible to anyone who has access to the internet. With this app, users should be able to use this web app in personal computers, tablets, or smartphones. The second web app however was created for a manager who has authority to manage the web-based tree information system. This web-based tree information system is specifically designed to create maps, analyze data, share and collaborate. A web app for trees on Prof. Dr. Necmetting Erbakan and Alpaslan Türkeş boulevards was created with ArcGIS Online. Any user can connect to ArcGIS Online through the ArcGIS Desktop ArcMap application or through web browser and access online content and capabilities free of charge.

\section{ACKNOWLEDGEMENTS}

This study was funded by the Scientific Research Projects Coordination Unit of Kahramanmaras Sutcu Imam University (KSU BAP) with project no: 2016/3-69 M. The authors gratefully acknowledge this support. We would also like to take this opportunity to 
thank landscape architecture undergraduate students, Ela Amer, Serhat Genç, Joud Sayed Taha, Rama Sayed Taha and graduate student, Ayşegül Kamış for their help during the tree inventory.

\section{AUTHOR CONTRIBUTIONS}

Hakan Oguz: Conducting tree inventory, organizing and analysing data, designing database, building web-based tree information system, creating the two web applications, writing, editing and reviewing the manuscript, funding acquisition, and supervision. Alper Uzun: Tree identification. Sule Kisakurek: Gathering information for application areas and potential hazards/benefits of trees.

\section{REFERENCES}

Abd-Elrahman, A. H., Thornhill, M. E., Andreu, M. G. \& Es-cobedo, F. (2010) A community-based urban forest inventoryusing online mapping services and consumergrade digital images. Int J Appl Earth Obs Geoinf, 12(4), 249-26

Bruno, G., Gasca, E., \& Monaco, C. (2014) The efficient management of park resources: Naturaland cultural data in the Alpi Marittime Park area. Information Systems, 42, 7888.

Gül, A., Özgüner, H., \& Serin, N. (2005) Kent Ormanlarının Yararları ve Kentsel Alanda İnsan-Orman Etkileşimi, 1. Çevre ve Ormancılık Şurası, Tebliğler, 2. Cilt, Mart, Antalya. 434-441.

Gül, A., Topay, M., Tuğluer, M., Uzun, Ö.F., \& Keleş, E. (2014) Kent Ağaçlarının CBS Ortamında Envanterı ve 3 Boyutlu Olarak Oluşturulması, III. Uluslararası Odun Dışı Orman Ürünleri Sempozyumu, Kahramanmaraş.

Li, M., \& Qi, M. (2003) MAPBOT: a Web based map information retrieval system. Information and Software Technology, 45(10), 691-698.

Oguz, H., Buyukturkmen, B., Kocahal, Y.E., \& Gitmis, E. (2018) Web-Based Tree Information System for Urban Parks: A Case Study of Alija Izetbegovic Park, Kahramanmaras-Turkey, In Proc: The International Congress of Science, Education and Technology Research, Odessa, Ukraine.

Oguz, H., \& Cayraz, O. (2019) Web-Based Urban Park Information System: A Case Study of Mothers Park, Gaziantep-Turkey, 1st International Applied Sciences Congress, 20-22 December, Malatya.

Oguz H., \& Isbir R. (2017) Developing a Web-Based Tree Information System: A Case Study of Cakmakci Sait Park - Kahramanmaras / Turkey. In Proc: The 3rd International Congress on Environmental Research and Technology (ICERAT), Belgrade, Serbia, p 21.

Oguz, H., Kıraççakal1, T. \& Kırteke, M. (2017) Web-Based GIS of the Haci Hasan Efendi Park, In Proc: International Advanced Researches and Engineering Congress, Osmaniye, Turkey.

Oguz, H. \& Kisakurek, S. (2016) Developing a Web-Based Tree Information System: A Case Study of Kilavuzlu Park - Kahramanmaras, 4th International Geography Symposium Kemer, Antalya, TURKEY p 165. 
Oguz, H. \& Kisakurek, S. (2016) UrbanParks - A Web-Based GIS Application: A Case Study of 12 Subat Park - Kahramanmaras, In Proc: 1st International Symposium of Forest Engineering and Technologies, (FETEC), Bursa, Turkey, p 65.

Sabuncu, A., Doğru, A., Özener, H., Turgut, B. \& Halıcıŏlu, K. (2013) Anıt Ağaç Envanterinin Coğrafi Bilgi Sistemleri ile Oluşturulması, TMMMOB Coğrafi Bilgi Sistemleri Kongresi, 11-13 Kasım, Ankara.

Wolf, K. (1998) Urban Nature Benefits: Psycho-Social Dimensions of People and Plants, Center for Urban Horticulture, University of Washington. 